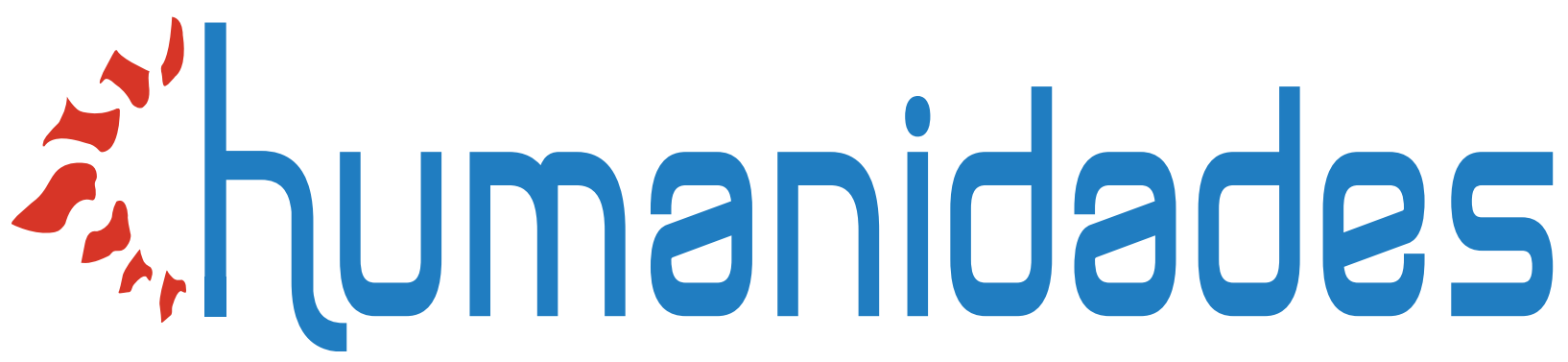

Women in Shahnameh: An Overview on Mythical, Lyrical and Social Aspects

Elaheh Rahmanian Reza Ashrafzadeh

DOI: https://doi.org/ I0.155 I7/h.v10il.398I6 https://revistas.ucr.ac.cr/index.php/humanidades/index 


\section{"humanidades}

Revista Humanidades

ISSN: 2215-3934

humanidades@ucr.ac.cr

Universidad de Costa Rica

Costa Rica

\section{Women in Shahnameh: An Overview on Mythical, Lyrical and Social Aspects}

Elaheh Rahmanian, PhD. Candidate; Ashrafzadeh, Prof. Reza

Women in Shahnameh: An Overview on Mythical, Lyrical and Social Aspects

Revista Humanidades, vol. 10, núm. 1, 2020

Universidad de Costa Rica, Costa Rica

Disponible en: http://www.redalyc.org/articulo.oa?id=498060395013

DOI: https://doi.org/10.15517/h.v10i1.39816

Todos los derechos reservados. Universidad de Costa Rica. Esta revista se encuentra licenciada con

Creative Commons. Reconocimiento-NoComercial-SinObraDerivada 3.0 Costa Rica. Correo electrónico:

humanidades@ucr.ac.cr/ Sitio web: http: //revistas.ucr.ac.cr/index.php/humanidades

Esta obra está bajo una Licencia Creative Commons Atribución-NoComercial-SinDerivar 3.0 Internacional. 


\title{
Women in Shahnameh: An Overview on Mythical, Lyrical and Social Aspects
}

Mujeres en Shahnameh: una visión general de los aspectos míticos, líricos y sociales

PhD. Candidate Elaheh Rahmanian

Islamic Azad University, Irán

DOI: https://doi.org/10.15517/h.v10i1.39816

rahmanian48@yahoo.com

Redalyc: http://www.redalyc.org/articulo.oa?

(D) http://orcid.org/0000-0002-9162-3945

Prof. Reza Ashrafzadeh

Islamic Azad University, Irán

drreza.ashrafzadeh@gmail.com

(iD http://orcid.org/0000-0002-5392-9273

Recepción: 23 Septiembre 2019

Aprobación: 19 Noviembre 2019

\begin{abstract}
:
Shahnameh is the most significant Persian epic masterpiece and it is the world's lengthiest epic poem written by a single poet. Shahnameh mainly describes mythical and historical dimensions of the Persian Empire in series of stories. The manifestation of love in the stories of Shahnameh is a real stimulus to prowess and epic. In this regard, Ferdowsi delicately paid attention in developing women characters of Shahnameh. In this article, it is tried to investigate mythical, lyrical and social aspects of women in different sections of Shahnameh. Mythical aspects of Shahnameh including zoroastrian beliefs are reviewed. The lyrical bases including poetry, playing, loving and marriage are considered in this research. And many women such as Roodabeh, Tahmineh and Jarirehwho contribute to lyrical aspects of Shahnameh are found and their character and other related dimensions are investigated and described. Interestingly it is found that in Shahnameh stories, gallantry alone cannot help a hero reach his goals unless love and affection are combined with it. Also, our research shows that some women in Shahnameh express their love consciously over their beloved man. Further, social roles of women in the romantic stories are categorised in political, martial, and artistic forms and further discussed.
\end{abstract}

KEYwORDS: Woman, Lyrical, Shahnameh, Social, Ferdowsi.

\section{Resumen:}

Shahnameh es la obra maestra épica persa más importante y es el poema épico más extenso del mundo escrito por un solo poeta. Shahnameh describe principalmente las dimensiones míticas e históricas del Imperio persa en una serie de historias. La manifestación del amor en las historias de Shahnameh es un verdadero estímulo para la destreza y la épica. En este sentido, Ferdowsi prestó atención delicadamente en el desarrollo de personajes femeninos de Shahnameh. En este artículo, se intenta investigar aspectos míticos, líricos y sociales de las mujeres en diferentes secciones de Shahnameh. Se revisan aspectos míticos de Shahnameh, incluidas las creencias zoroastrianas. Las bases líricas que incluyen poesía, juego, amor y matrimonio se consideran en esta investigación. Y se encuentran muchas mujeres como Roodabeh, Tahmineh y Jarireh que contribuyen a los aspectos líricos de Shahnameh y se investiga y describe su carácter y otras dimensiones relacionadas. Curiosamente, se encuentra que en las historias de Shahnameh, la galantería por sí sola no puede ayudar a un héroe a alcanzar sus objetivos a menos que el amor y el afecto se combinen con él. Además, nuestra investigación muestra que algunas mujeres en Shahnameh expresan su amor conscientemente sobre su amado hombre. Además, los roles sociales de las mujeres en las historias románticas se clasifican en formas políticas, marciales y artísticas, y se discuten más a fondo.

Palabras Clave: Mujer, Lírica, Shahnameh, Social, Ferdowsi. 


\section{INTRODUCTION}

The Shahnameh ("Book of Kings") is Persian literature masterpiece written by Ferdowsi thousand years ago. It is believed that Shahnameh is the world's longest epic poem created by a single poet. This masterpiece has got worldwide attention and many recently have studied this works such as Lewis (2015).

The Shahnameh is the Book of Life, it is about people's lives who have been alive with all being as if there has been no death at all. Various topics including wisdom, ethics, romance and lyric, pain, counsel and campaigns are mentioned in Shahnameh. In romance and lyrical subjects, the devotion of love in Shahnameh depends on the general circumstances and characteristics of each time period. Dr. Yusufi (1977) writes about the love of chivalrous heroes in Shahnameh:

The love stories of Shahnameh are not only redundant, but also they are often in the direction and progression of national epics. If Shahnameh was not supposed to talk about women and love, its perfection would be diminished. In his love stories, Ferdowsi combines harmonious words and lyrical images, and forms delicate music and sweet tune in his poetry that makes it all wonder.

An important feature of the love story of Shahnameh is the miniature model of the outer and inner character of their female heroes.

The truth is that an epic work is not entirely about warfare and arrogance, rather it is inner features of an epic work making it eternal and permanent. Love and devotion, which are the motif of lyrical literature, have a vast prolific usage.

So far, many have researched on the women of Shahnameh and analysed their personalities. Among these works, The Stories of Women of Shahnameh by Zahra Mohazeb (1995), Women of Shahnameh by Jamal al-Din Haeri (2004), "Woman in Shahnameh" by Dr. Mahdokht Pourkhaleghi (2005), and "Women in the Shahnameh: Exotics and Natives, Rebellious Legends, and Dutiful Histories" by Davis (2007) can be referred. More recently, Women in the Shahnameh (2012), written by Professor Djalal Khaleghi Motlagh in German in 1971, has been translated from German to English by Neuenschwander and Pirnazarin in 2012. This book summarises the stories of the most important women and further studies their positions. Loveimi (2016) also reviewed the role of some important women who change the fate of the heroes in Shahnameh.

This study presents a review on mythical aspects of women in Shahnameh and further it provides a better understanding on lyrical and social aspects of women in Shahnameh. In addition, the influence of lyrical aspects on heroes of epic stories is analysed in the current study.

\section{Discussion}

\subsection{The mythical aspects of women in Shahnameh}

The myth is the visualization of human emotions (Amozegar, 1995, p. 5). There are two kinds of perceptions about myth: (1) fiction and lies, and (2) truth and history.

In ancient cultures, many nations considered the origin of creation and life as a feminine principle which can have devilish or Ahoori (divine) aspects (Shamisa, 1993, p. 59). This principle is also one of the important features of the twelve thousand years of Persian mythology (Amozegar, 1995, p. 13). The belief in the female creator shows that women in the myth have a prominent and important role. Further, in the myth for the creator of universe -Ahura Mazda ${ }^{1}$-, seven female angels are considered as her daughters. These angels, each named Amshapasand, are of unique duties and have positive and negative personalities.

Women's expression in the form of a goddess of poetry is also very important. Male poets and musicians believed that they would not be able to create works until the poetry of the goddess was drawn to them. However, Arabs considered for every male poet an inner female devil and for every women poet, an inner 
male devil. They called the female devil 'Tabee' and the male devil 'Tabe' who reveal the poem to the poet (Huart, 1966).

In Shanameh, 'Keyumars' is the first man. When the devil becomes aware of his existence, sends him a female demon called 'Jahy' to poison him. As a result, Keyumars dies at the age of thirty and useful metals are produced from his body. Zar is created from his reproductive system. This Zar, which is like the daughter of Ahura, has been nourished in the heart of the earth for forty years (Khashe, 1990, p. 126).

Goddess of Persian myth is Aredvi Sura Anahita (Anahita), Nahid, or Anahid, is distinguished goddess who has an important status in ancient Persia and her adoration dates back to much earlier periods and even before Zoroastrian times. Nahid or Anahita was a mythological positive character, the goddess of water. In describing this female goddess, it was said "she is a young, tall, good looking, well-dressed, and uplifting woman" (Amozegar, 1995, p. 21).

On the contrary, 'Pary' is one of the negative women characters of a woman in Persian mythology. Pary ('Paeir Kia' in the Avesta) character is defined as a sophisticated and very beautiful being from an invisible world and it is due to her wonderful beauty that she can deceive men easily. This character, in the thoughts of today's nations, has a popular and desirable image (Bahar, 1998, pp. 163-261).

By the other hand, Ishtar is a bisexual angel whose character changes with time. For example, she is the goddess of love in mornings, while she becomes the goddess of war in evenings (Khashe, 1990, p. 148).

Sometimes Ferdowsi adds mythical aspects when he describes a character. For example, he describes a woman's hair as a lasso that will throw the enemy off or attract the lover. From his point of view, Tar Gisso (Persian women's hair) is not a frizzy hair but it is straight like a chain that closes hands (referring to some stories). Nevertheless, women's heroes in Shahnameh are human beings even though they come from the mythical world of fairy tales to humorous narratives.

\subsection{The lyrical dimensions of women in Shahnameh}

Shahnameh is not a book against women. Most women in Shahnameh are role models. While they are beautiful, wise, high-minded, and brave, they are feminine and full of passion. This depiction of women has not been seen in Persian works and may not be seen in other great ancient works of other countries. Women like Sindokht, Roodabeh, Tahmineh, Farangis, Jarire, Manijeh, Gordafarid, Katayon, Gardie, and Shirin have stirred up love and respect, and they have both inside and outside beauty (Eslamy Nodoshan, 1969, p. 61).

Ferdowsi describes the lovers in his stories with the most beautiful words. In Ferdowsi's point of view, a woman is beautiful when she is blended with the purity and grandeur of Persian women. Describing beauty of a woman in Shahnameh is influenced by the nature of each epic environment. Sometimes the motive for creation of a story is love, sometimes is a battle for the survival of the nation, and sometimes is an epic story with the tragedy context like Rostam and Sohrab (Hamidi, 2006, p. 214). The most beautiful description of Ferdowsi from the woman is the description of Roodabeh. For instance, Roodabeh is the woman who is distinguished as tall and stretched with refreshed rosy face, red lips, small mouths, pearl teeth black eyes, arched eyebrows and black long hair. Ferdowsi's goal in the story of Roodabeh is creating love; therefore, he devoted himself entirely to describing her attractiveness.

Love stories in Shahnameh are divided into three categories:

1. The romantic stories that are occurring along the epic and are themselves a significant contributor to the ethnic national destiny, such as Zal and Roodabeh, Tahmineh and Rostam, Bijan and Manijeh, and Kavous and Sudabeh. This category of romance is mostly related to Shahnameh's heroic section. This kind of love is called "heroic love stories". 
2. The love stories that only occur at a particular stage for epic heroes, which are temporary events and do not usually impact the story results. As an example, the love adventures of Bahram Gur with four sisters of a miller. These stories are mostly related to the historical part; we call these "whimsical stories".

3. There is another type of whimsical stories in which the love of a lower class woman (or of an alien ethnicity) for an epic hero which saves him from a difficult situation and then it is forgotten. The story of Golnar and Ardeshir, or Shapur and Queen Taer can be considered in this category. We will name this kind of love story as "love and forgetfulness".

In the romantic stories, most of the women are famous foreigners: Roodabeh and Sindokht, their mothers are from Kabul; Farangis, Manijeh, Jarireh, Tahmineh, and also Siavash's mothers are Turanian; Sudabeh is from Hamavaran and Katayun, Garshasb's wife, is Roman. All these women are beautiful and their beauties have been described in the same way. In most of these stories, qualities of women are in line with the imaginations of ancient men from women. These women are bold lovers who faithfully stay with their love, except for Sudabeh. As an example, Roodabeh is the faithful lover of Zal. Tahmineh, the daughter of the king of Samangan, falls in love with Rustam through what she heard about him. And both of these women are strangely combined love with virtue (Eslamy Nodoshan, 1991, p. 16).

Elegy plays a significant role in lyrical aspect of Shahnameh. Elegy has a very solid emotional foundation as the poet expresses his/her feelings and emotions (Shamisa, 1991, p. 255). It also has the most important element of poetry, i.e. imagination. In fact, elegy combines emotion and imagination (Imami, 1990, p. 9). The elegy can have different kinds; it can be about the death of the king and the minister or one of the men of science and literature; it can be about the death of a relative or friend (Shamisa, 1991, pp. 255-257). Ferdowsi is so successful in reciting elegies that Shahnameh stimulates emotions and sentiments as eyes are crying and the hearts are sad. Perhaps the most beautiful words of the Shahnameh are words about elegies of the survivors after death or martyrdom (Sarami, 1989, p. 288). Women of Shahnameh also have the art of reciting elegies such as Roodabeh, Tahmineh, and Roshanak (Bahram Chobine's sister).

There are many poems by famous poets about the relationship between the mother and child. Motherto-child love has been depicted throughout Shahnameh like Tahmineh and Sohrab, Farank and Fereydoun, Sindokht and Roodabeh, Farangis and Keykhosrow, Siavash's mother. Some of these mothers like Jarire, Farank, Katayon, Farangis, and Sindokht have shown to be stronger in emotion. Jarire is the most emotional one. She is the merciful wife of Siavash and mother of Forod. She was a teenage girl who married to Siavash on her father's suggestion. In the very first years of her married life, she loses her courageous and beloved husband Siavash. She supports and protects her beloved son for many years. Her suicide after her child's death is very mournful. Immediately after her son's death, she puts her face on the boy's face and tears her tummy and dies next to him, so that she would not be captured by the attackers (Yahaghi \& Ferdowsi, 1991, pp. 37-65 and pp. 456-893).

\subsection{The social dimensions of women in Shahnameh}

Aside from being lover or mother of heroes, some women in Shahnameh are influential characters. Among the past literature, Shahnameh is one of the few masterpiece books in which women play fundamental roles. In Shahnameh, we run into some women who have great and incredible impact son the occurrence of some events (Dabir Yasaghi, 1986, p. 50).

Ferdowsi introduces women as the representative of their community and their society. In addition to their beauty and appearance, their inner beauty is admired and consultation with them are given a special place in Shahnameh.

In many cases, women are considered at the same level as men and sometimes even superior to men. For example, it is noted that $\mathrm{Kyani}^{2}$ champions of Shahnameh expressed their mothers' integrity and greatness 
to be as great as their fathers' ones while they boast about their conquests before commencing their duels (Hejazi, 2006, p. 314). Most women in Shahnameh are characters with moral qualities. Some of the main women qualities in Shahnameh are discussed below:

The chastity that can be found in Tahmineh, Farangis, Jarire, Katayon, and Shirin. For example, Shirin who is the ladylove of Khosrow behaves morally in her interactions with Khosrow and others.

1. Reserved: Being reserved had been considered as one of the femininity indicators in Shahnameh.

Rudabeh is one of the interesting characters in Shahnameh. She shows a certain reserved behaviour against her parents although she ignores the ethos and secretly, and with wonderful charm, throws Zalher very long hair as rope to bring him to her palace.

2. Loyalty: Some women in the Shahnameh are perfect examples of loyalty, especially in times of difficulty. They even confront their fathers in defence of their husbands. In this regard, it has been said that 'in Shahnameh, loyalty is one of the highest qualities of a woman. Women's loyalty has been the greatest stimulant of human social life, and the greatest manifestation of women's loyalty is her loyalty toward her partner (Hashemi, 1991, p. 83). The excellent example of this loyalty can be found in women such as Sudabeh, Farangis, Sipivand, Manijeh, and Shirin. Sudabeh, with all her bad deeds, is the true figure of a loyal woman as she stays loyal to her husband even when she is a captive in the prison of king of Hamavaran.

3. Independence: some women in Shahnameh have independent characters. They are self-reliant in performing their work. Among these women Hast, Pourandokht and Azram Dukht can be mentioned. Qidafe, Queen of Andalusia, is a happy and informed woman who always rulled in independence. When Alexander asked for tribute from her, not only she intelligently drops Alexander's plans, but also she gets his support by an agreement (Yahaghi \& Ferdowsi, 1991, pp. 46-67 and pp. 668-1050).

4. Eloquence: Sindokht is among the women who are eloquent of speech. When she wanted to inform her husband Mehrab about her daughter being fall in love, she prepared some words to prepare the ground first as she knew that he would become angry once he hears the news.

5. Tact of woman: Most of the women of Shahnameh are competent. Sinddokht, Farank, Arezo are among the women who resolve problems with their knowledge and tact. Sindokht is a clever woman who was aware of political and social issues of her era and plays an influential role in Shahnameh. Her ingenuity in opening the deadlock in the love story of $\mathrm{Zal}$ and Roodabeh is evident. She also resolves problems of his husband Mehrab.

6. Modesty: Unlike what has been seen in other nations historical culture, especially in the ancient Roman, the daughters of Ahura were not only belonged to a particular socio-economical class such as Royal families and gladiators. Instead, they could interact with the general public from all social classes, and their modesty was one of their main qualities (Khashe, 1990, p. 148).

7. Hospitality: Some women of the Shahnameh are kind hosts for their guests and they welcome their guests sincerely with whatever they have. As an example, Palizban's wife is a hospitable woman. Bahram, one of the kings in Shahnameh, arrived to the village on his way to Turan, he saw a woman holding a jar on her shoulder. He was hungry and thirsty, and asked the woman to feed him. The Palizban's wife welcomed him to their house and provided him some food in good faith.

In general, a popular woman in Shahnameh is who has valuable characteristics of Persian culture, physically and mentally attractive and also have qualities that are consistent with social conventions. On the contrary, hateful women are depicted as individuals who are captured by their own desire, self-centred, rebellious, calculating, believed in black magic, immoral and who are not able to keep secrets. The latter feature has been named as one of the greatest women defects in the Shahnameh. Nevertheless, Ferdowsi, on the contrary to social conventions of his time, does not judge a woman on the basis of her sexuality. Hence, wisdom of Shahnameh is mixed with a matriarchy and not femininity as a tool (Bigdeli, 1999, p. 16).

In describing the images of women, besides describing the outside world, i.e. women appearance, Ferdowsi has paid attention to the inner world and has traced delicate lines of their personalities. In fact, Shahnameh 
is more focused on the inner world than the outer world. Therefore, the diversity of the women appearance in Shahnameh is not very much compared to their personalities. Three different personality types have been found in Shahnameh:

1. Martial personality: Gordie is a sister of Bahram Chubin. The woman in the role of a brave, fearless and agile character who fled to China with her brother and was proposed to Khaqan after the death of Bahram. Asshe refused to marry him, she prepared an army to confront the Khaqan Corps. She is a woman who is in the position of general. A brave woman who acts like an experienced commander in the arrangement of the army, the instigation of courage, and the excitement of the army. She wears masculine armour and she has to conceal her femininity in her armour because her femininity would convinced the opponent to have an easy fight and also would give him spirit. So the woman must use the man's dress so that she can frighten (Pak Nia, 2009, p. 108).

2. Political personality: Homay is one of the most important women in the Shahnameh who reaches the power. Bahman marries his daughter Homay. But at the time of her pregnancy, he becomes ill and instead of his son Sassan, Homay succeeded him. Homay started another ritual in the tradition of the kingdom. The behaviour of Homay on the throne can confirm this belief that advent of women in the realm of politics, makes the world of politics to consider mercy which is usually a female trait, instead of place of violence and competition which are generally results of male traits (Pak Nia, 2009, p. 94). At the very beginning of her kingship, she invites people of the world to justice. During her thirty-year kingship, she is able to establish justice in her realm. She sends a great army to Rome, defeats Romans and rules over her neighbouring tribes. Homay rules for a long time, undoubtedly because of her particular ruling capability.

3. Artistic personality: Most women in Shahnameh are not so brave and warrior. Most women have feminine professions, and some with occupations of entertaining men and tools for pleasure and joy. However, one of artistic character in Shahnameh is Arezo who is a musician. She is daughter of a shepherd, and Bahramget married to her after he hears about her capability from her father. In the story of Bijan and Manijeh, playing music by beautiful women has also been mentioned.

Some of the other social aspects about women in Shahnameh are as follow. Ancient Persian girls are confident in dealing with men and some of them have gone on to declare their love and even to propose for marriage (Hejazi, 2006, p. 260). They are pioneer in love, this means the expression of love by the woman and the response from the man. For example, when Rostam arrives in Samangan city looking for his lost horse, he becomes a guest of the king of Samangan. At night, with a candle on hand, Tahmineh advances towards the Rostam's bed and she informs him about her love and the motive for having a son from Rostam. The meeting scene of Tahmineh and Rostam is very passionate and represents the spirit of women's freedom and pride in expressing a natural and legitimate demand that is accepted by culture of the society too. So it is accepted by social conventions of the time to give a woman the right to choose her spouse (Mohazeb, 1995, p. 58). In the case of Tahmineh and Rostam, Rostam ultimately proposes Tahmine to marry him by Mobad (Zoroastrian clergy) and she marries him according to the Zoroastrian religion. Similar approach is observed in the romantic relationship of Sudabeh to Siavash, Golnar to Ardeshir, and Arezo to BahramGur (Yusufi, 1977, p. 1-15).

It is also interesting to know that in ancient Persian, people believed that stars have influence on human fate. Therefore, they looked for them to help solve their problems. The significance of the predictions was so high that all kings of Persia had astronomers at their court to inform them of the details of upcoming events including marriage. In the marriages of Shahnameh, astronomers were helped to reveal the details of upcoming marriages. They predicted the fate of human beings with an instrument called the Ostorlab (Masumi, 2003, p. 251). As an example, at the wedding ceremony of Zal and Roodabeh, they asked astronomers to predict the future of their marriage before they get married. They married to each other after the astronomers anticipated the birth of an athlete son as the result of this marriage. 
Sometimes, nursemaids play an important role in bringing lovers together. For instance, Roodabeh shares her love with nursemaids and asks them for help to mediate. As the result, these two lovers come together. Also, In the story of Bijan and Manijeh, Manijeh sends her nursemaid to Bijan to invite him to her room, and eventually they come together with her mediation.

\section{Conclusion}

Shahnameh as the most influential epic works in Persian literature expanded deliberative thoughts, educational and ethical insights together with Persian tradition and Persian school of chivalry. There are many truehearted and competent women in Shahnameh. However, this enormous book mentioned the name of thirty-two women and also a number of prominent women, without mentioning their name.

Women dimensions in mythical, lyrical and social aspects are investigated. The women play substantial roles in Persian myth as Goddess of Persian myths Aredvi Sura Anahita (Anahita). Further, in the Persian mythology the creator of universe -Ahura Mazda- has seven female angels who are considered as her daughters.

However, lyrical dimensions of Shahnameh overshadow all other aspects. Facially, all attractive women have long hair, elegant faces, tall, black eyes, bright faces, and red lips. However, depiction of women varies according to the nature of the story. For example, Ferdowsi combines women description with the elements of war such as bow and lasso influenced by the epic environment.

Further, three lovey story categories are found in Shahnameh: heroic love stories, whimsical stories and love and forget fullness. It is clear that there is a strong link between epic features and love in the Shahnameh. It is always about life of a hero and his love adventures like the story of Golnar and BahramGur, Zal and Roodabeh, and Bijan and Manijeh. In fact, in Shahnameh, love is the true stimulus for bravery, epic, and battle. Hence, apart from the hero who is on the one side of the story, his lover who is actively involved in the story events plays an important roleone the other side. The woman's lyrical character in the epic stories of Shahnameh makes a hero to do incredible things due to the strong love link. As the result it may appear to readers that heroes are at the center of events, which may not totally be true.

In the social aspects, the main qualities of women in Shahnameh are studied. As a result, loyalty and not being able to keep secrets are considered the best and worst qualities of a woman in Shahnameh, respectively. Further, three different social personality types, i.e. martial, political, and artistic are found in the performed study. Some of these women have role-playing positions in the society while they do not overlook about their love and feelings. This demonstrates the position and rank of women and their influence in the society of the time.

It is also worth noting that some women of Shahnameh such as Manije, Tahmina, and Sudabeh are reckless and at the same time consciously express their love toward their favourite men. There are many similarities in their appearance and behavioural attributes, which suggests a social unit in these stories. The social context in which these stories originated is a free, unrestrained, aristocratic community in which women have fairly acceptable freedom. In addition, women in Shahnameh are realistic, and knowing their body and soul's need, they strive to reach their demands.

\section{Agradecimientos}

Authors would like to thank Dr. Abolghasem Naghib for his effort and help with translating the original manuscript from Farsi to English and further editing. 
PhD. Candidate Elaheh Rahmanian, et al. Women in Shahnameh: An Overview on Mythical, Lyrical and S...

\section{ReFERENCIAS}

Amozegar, J. (1995). Mythological History of Iran. (3 ed.). Tehran: Tehran: Samt Publications.

Bahar, M. (1998). From Myth to Date. (2 ed.) Tehran: Cheshmeh Publishing.

Bigdeli, Ahmad (1999). Woman in the Mirror of the wisdom of Shahnameh (A series of strategic discussions in Persian literature). Tehran: Publication, Perspective of Iran.

Dabir Siaghi, M. (1986). Ferdowsi, woman, tragedy. Tehran: Ghatreh Publisher.

Davis, D. (2007). Women in the Shahnameh: Exotics and Natives, Rebellious Legends, and Dutiful Histories. In Poor S.S., Schulman J.K. (eds), Women and Medieval Epic (pp. 67-90). New York: Palgrave Macmillan.

Huart, C. I. (1966). A History of Arabic literature. Beirut: Khayats Publisher.

Haeri, J. (2004). Women of Shabnameh. Tehran: Yond no.

Hamidi, B. (2006). The culture of women of Shahnameh. Tehran: Pajwok of Keyvan publishing house.

Hashemi, M. (1991). Woman's position in Ferdowsi's Shahnameh. Journal of Knowledge, 27-28.

Hejazi, B. (2006). Review of the position of woman from the ancient era to the end of the Sassanian era. Tehran: Qeside Sara publishing house.

Imami, N. (1990). Poem Reading in Persian Literature. Tehran: University Press Center.

Eslamy Nodoshan, M. A. (1969). Men and Women of Shahnameh. Yaghma Magazine, 2, 22.

Eslamy Nodoshan, M. A. (1991). Voices and Mentions. Tehran: Arian Publishing.

Khashe, S. (1990). Review of Cinematic Book. Tehran: Cultural research office affiliated with cinematic centres.

Khaleghi Motlagh, D. \& Pirnazar, N. (Ed.). (2012). Women in the Shahnameh. B. Neuenschwander (translator). USA: Mazda Publisher.

Lewis, F. (2015). The Shahnameh of Ferdowsi as World Literature. Iranian Studies, 48(3), 313-336. DOI: $10.1080 / 00210862.2015 .1023063$

Loveimi, Soheila (2016). Fateful Women in Ferdowsi Shahnameh. English Language Teaching, 9(5), 46-53. DOI: $10.5539 /$ elt.v9n5p 46

Masumi, D. (2003). Marriage in Shahnameh. Isfahan: Naghsh e Khorshid Publisher.

Mohazeb, Z. (1995). Stories of Shahnameh Women. Tehran: Cultural Center.

Pak Nia, M. (2009). Roodabeh and Sudabeh, Al-Zahra. Tehran: University Press.

Pourkhaleghi, M. (2005). Woman in Shabnameh. Mashhad: Beh Nashr Publisher.

Sarami, G. (1989). From the Colour of Flower to History of Thorns: The morphology of the Shahnameh stories. Tehran: Scientific and Cultural Publisher.

Shamisa, S. (1991). Literary Types. Tehran: Garden of Mirror Publishing.

Shamisa, S. (1993). The Story of a Soul. Tehran: Ferdows Publications.

Yahaghi, M. J. \& Ferdowsi, A. (1991). Shahnameh Ferdowsi (Based on Moscow Version). Mashhad: Sokhan Gostar Publisher.

Yusufi, G. H. (1977). Leaves in the Wind. Tehran: Toos Publishing House.

\section{NoTAS}

1 Ahura Mazda is the creator of the universe in Zoroastrianism which is ancient pre-Islamic religion of Iran

2 Refer to Kiyanian Dynasty

Todos los derechos reservados. Universidad de Costa Rica. Esta revista se encuentra licenciada con Creative Commons. Reconocimiento-NoComercial-SinObraDerivada 3.0 Costa Rica. Correo electrónico: humanidades@ucr.ac.cr/Sitioweb: http: //revistas.ucr.ac.cr/index.php/humanidades 
Revista Humanidades, 2020, 10(1), Enero-Junio, ISSN: 2215-3934

CC BY-NC-ND 